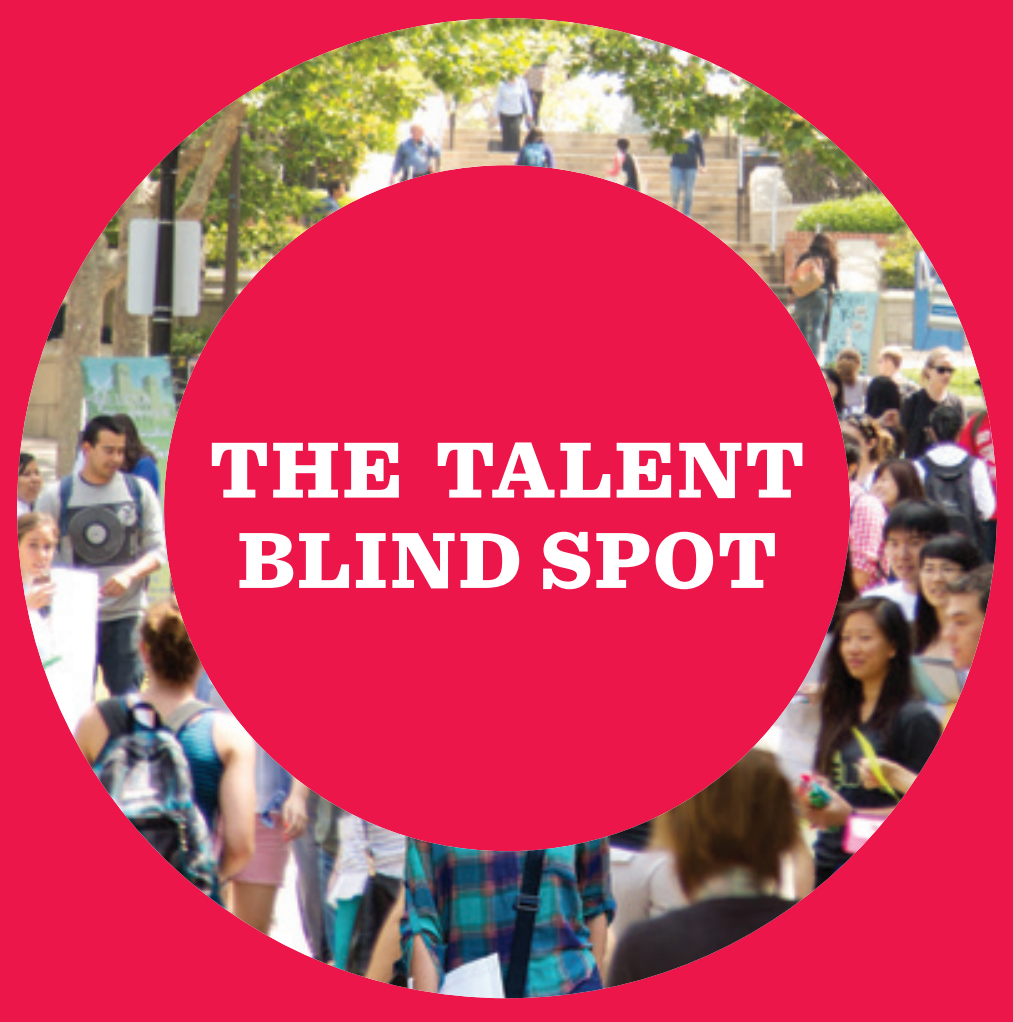

The Case for Increasing Community College Transfer to High Graduation Rate Institutions 


\author{
AUTHORS: \\ Tania LaViolet \\ Benjamin Fresquez \\ McKenzie Maxson \\ Joshua Wyner \\ The Aspen Institute College \\ Excellence Program
}

\title{
THE AMERICAN TALENT INITIATIVE:
}

The American Talent Initiative (ATI) is a Bloomberg Philanthropies-supported collaboration between the Aspen Institute's College Excellence Program, Ithaka $\mathrm{S}+\mathrm{R}$, and a growing alliance of colleges and universities dedicated to substantially expanding opportunity and access for low- and moderate-income students. By 2025, ATI aims to attract, enroll, and graduate an additional 50,000 lowerincome students at the 290 colleges and universities that consistently graduate at least 70 percent of their students in six years. "ATI members" are a subset of these 290 and include a mix of public and private colleges and universities from all over the country.

\section{ACKNOWLEDGMENTS:}

The authors of this work would like to thank:

- Martin Kurzweil, Elizabeth Pisacreta, and Emily Schwartz of Ithaka S+R for their analytics support and editorial expertise in the crafting of this guide.

- Alfred Herrera, Emily Froimson, Lynn Tincher-Ladner, Paulina Palomino, Stephen Handel, and Susan Lanspery for their thought partnership in identifying key practices and policies needed for transfer student success.

- The community college and four-year presidents, administrators, faculty, staff, and students from institutions featured in this report, who generously shared their time, insights, and experiences in the development of this report.

ATI gratefully acknowledges Bloomberg Philanthropies for supporting this publication.

\section{A GUIDE TO USING THIS RESEARCH}

THE TALENT BLIND SPOT IS DIVIDED INTO TWO PARTS:

\section{THE CASE FOR INCREASING COMMUNITY COLLEGE TRANSFER TO HIGH GRADUATION RATE INSTITUTIONS}

- Understand the community college transfer landscape with data from the report.

- Download the companion slide deck to help make a strong case for transfer at your institution.
THE PRACTICAL GUIDE TO INCREASING COMMUNITY COLLEGE TRANSFER TO HIGH GRADUATION RATE INSTITUTIONS

- Use the "Fundamental Principles" as a strategy audit to assess how your institution compares to others.

- See what is possible by learning from the "Transfer-Friendly Ecosystems" of three exemplary institutions: Smith College, the University of North Carolina-Chapel Hill, and the University of California-Los Angeles.

- Read the "Transfer Tactics Repository" to access case studies of institutional practices that respond to specific challenges. 


\title{
A SECTOR WIDE CALL-TO-ACTION
}

\author{
The American Talent Initiative \\ (ATI) is a rapidly expanding alliance of \\ four-year colleges and universities with \\ graduation rates above ' 70 percent \\ that has committed, by 2025, to attracting, \\ enrolling, and graduating an additional \\ 50,000 low- and moderate-income students. \\ For decades, a wealth of evidence has \\ demonstrated that there are more \\ than enough exceptionally talented \\ students to meet this goal. ${ }^{1}$
}

\begin{abstract}
Most recently, 2013 research by Caroline Hoxby and Christopher Avery revealed that, each year, thousands of low-income high school graduates do not even apply to top colleges despite having the grades and test scores that make them competitive for admission. ${ }^{2}$
\end{abstract}

This body of research-together with a steady drumbeat of press coverage around underdeveloped talent-has sparked a renewed sense of urgency among many selective institutions and nonprofit organizations to expand opportunity. The vast majority of those efforts are aimed at talented, lower-income high school students, helping them attend and pay for top colleges and universities through, for example, better advising on "college match," promises for debt-free college, and revamped admissions processes.

While these efforts are laudable and necessary, they are predicated on the notion that the traditional high school-to-college pathway-once cleared of hurdles-will be accessed by most if not all highly talented students from lower-income backgrounds. The facts strongly suggest otherwise.

Hoxby, Caroline, and Avery, Christopher. (2013). The Missing "One-Offs": The Hidden Supply of High-Achieving, Low-Income Students. Brookings Papers on Economic Activity, Spring 2013 


\title{
CONSIDER THE FOLLOWING FACTUAL SCENARIOS
}

\author{
(NAMES CHANGED TO PROTECT STUDENTS' PRIVACY)
}

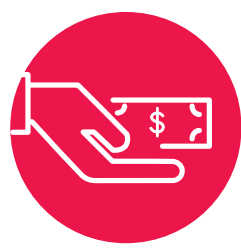

\section{Raymond Williams graduated near the top of} his high school class, but it was not financially feasible for him to enter a four-year program. He understood that substantial financial aid was available, but with his single mother unwell and three younger siblings still at home, he was a primary breadwinner and part-time caregiver. When his siblings grew up and could pitch in, Raymond thought, he would revisit his goal of going to a university.

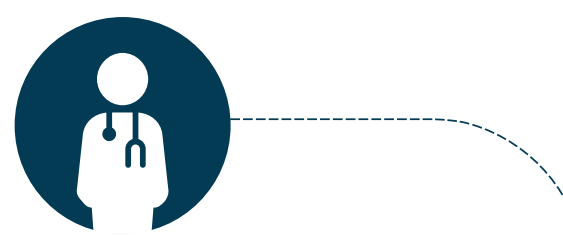

\section{While he didn't do badly, Jack Ingles found} little inspiration at his small rural high school. His parents didn't go to college, and going to a university never came up in conversations with his guidance counselor. So, Jack didn't think of himself as college material, and, even if he was, he didn't know what to study. After graduating, he moved from job to job and eventually got a job in a hospital. Now, with a little more life experience, he knows that he wants to serve in the health care field, probably as a doctor, although he is still open to other jobs in health care.

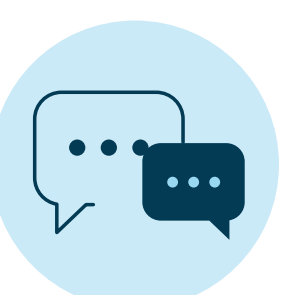

Mila Felix was a star student, earning straight A's in high school and acing her SATs.

Compelled to serve her country-just like her father and grandfather-Mila joined the military after high school and served two tours in Iraq. When she returned home ready to take the lessons she learned from her experience abroad and contribute to her community as a civilian, higher education was the obvious next step. But it had been years since she was in a classroom and, after retaking her SATs and receiving low scores, she was counseled against entering a four-year university by a family friend who worked at a nearby university.

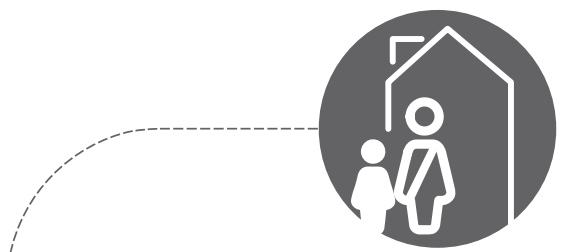

June Miller's son was born when she was a junior in high school. With daycare and other support from her family, she managed to graduate from high school with honors. June chose to stay close to home, so she could work to support her son while her grandparents provided childcare. Now, her son is old enough to start school, and she knows that it is time to continue her own education, so she can advance her career and provide a better life for herself and her family.

Coming from vastly different backgrounds, these four students have a few things in common: They are exceptionally talented,

they are motivated to succeed, they have valuable life experiences

to bring to the classroom, and they don't fit the mold of the

typical student top colleges and universities recruit. There's one more thing they share:

They are very likely to begin higher education at their local community college. 
Together, these brief stories illuminate some of the "non-traditional" paths to higher education followed by a substantial proportion of the nation's college-going population. Each fall, nearly 1.1 million students-representing communities across a diversity of races, ethnicities, geographies, ages, and income levels-begin higher education in two-year public colleges. ${ }^{3}$ Most of these students have clear aspirations: As many as 80 percent indicate that their ultimate goal is to transfer and attain a bachelor's degree. ${ }^{4}$ When they succeed in transferring to a four-year school, these students do just as well as their "traditional" student peers who started at four-year colleges and universities. Not only are these transfer students poised for individual success, but faculty often report that transfer students' perspectives, motivations, and life experiences enrich the academic and social experience for students in the classroom and beyond.

Unfortunately, the data reveal that too many community college students seeking to attain a bachelor's degree fail to even enter a university and, when they do, suffer the consequences of unclear pathways. As a result, only 14 percent of them attain a bachelor's degree within six years of community college entry. ${ }^{5}$ While many community colleges have recently been working hard to improve two-to-four-year transfer pathways, more can and should be done.

Due to geographic proximity and lower costs, regional public universities have tended to be the primary engine for bachelor's attainment for community college transfers. However, to fully serve the abundance of community college students seeking further opportunity, it should be incumbent upon the complete

\section{Each year more than 50,000 high-achieving community college students do not transfer to a four-year institution- 15,000 of these students have earned a 3.' GPA or higher in community college}

spectrum of higher education to ensure both higher rates of community college student transfer and bachelor's completion. The 290 colleges and universities with 70 percent or higher graduation rates-hereinafter referred to as "the ATI sector" or "ATI institutions"-have a mixed record of supporting transfer from community college. ${ }^{6}$ Not only does this limit the access of community college students, the evidence suggests that, by remaining on the margins, these four-year institutions overlook a pipeline that is extremely rich in the diversity and talent that they seek to recruit.

The research reflected in this paper estimates that, each year, more than 50,000 high-achieving community college students-defined as those who have over a 3.0 GPA and are enrolled in more than 24 credit hours in their first year-do not transfer to a four-year institution. Moreover, approximately 15,000 of these students have earned a 3.7 GPA or higher in community college-the equivalent benchmark for "high performance" predominantly found in the high school student college match literature.

These data validate what community college practitioners and research experts have known all along-community colleges are home to an abundance of talented students with the ambition to succeed. As ATI works toward its 50,000-by-2025 goal, we should include serving these students as a core part of our mission.

\footnotetext{
${ }^{3}$ U.S. Department of Education. "National Digest of Education Statistics, Table 305.10." National Center for Education Statistics, 2016.

Note: According to Tackling Transfer: A Guide to Convening Community Colleges and Universities to Improve Transfer Student Outcomes (see reference \#4), 1.7 million degree-seeking undergraduate students begin at 2-year public colleges over a 12-month period (as opposed to fall-start only), excluding dual-enrollment students.

${ }^{4}$ The Aspen Institute College Excellence Program. Tackling Transfer: A Guide to Convening Community Colleges and Universities to Improve Transfer Student Outcomes. Aspen Institute College Excellence Program and the Community College Research Center, December 2017.
} 
10.

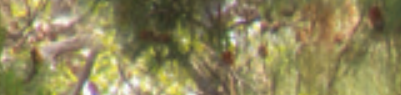

$+7+3$ on 1042

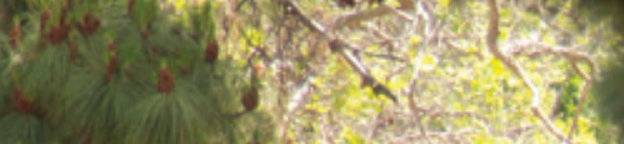

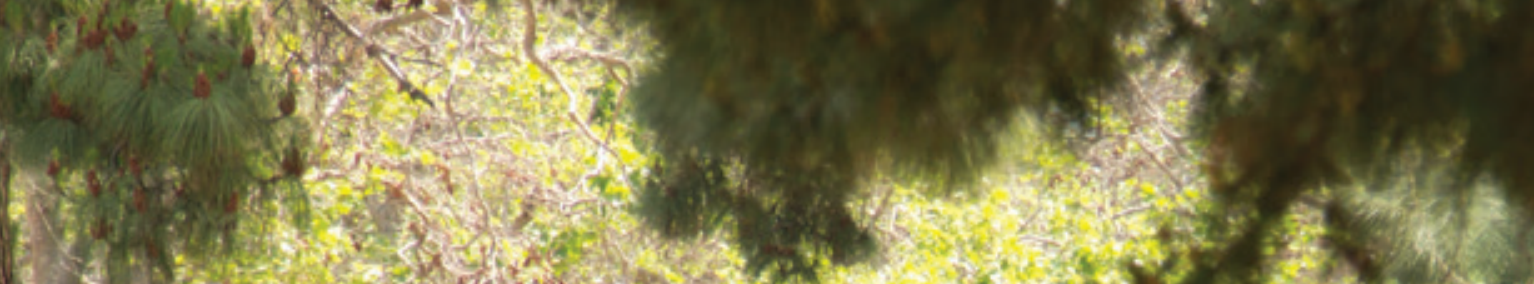

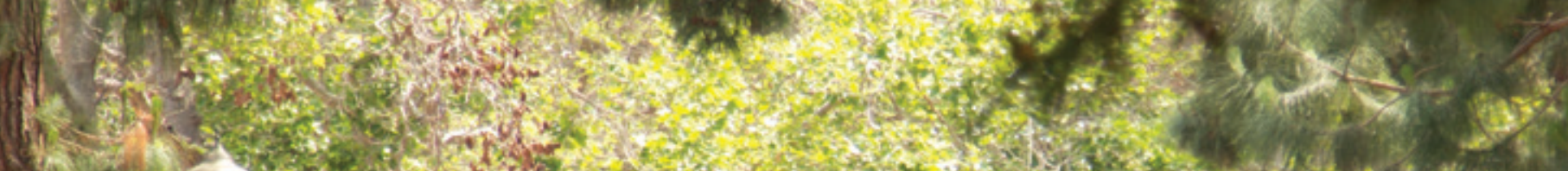

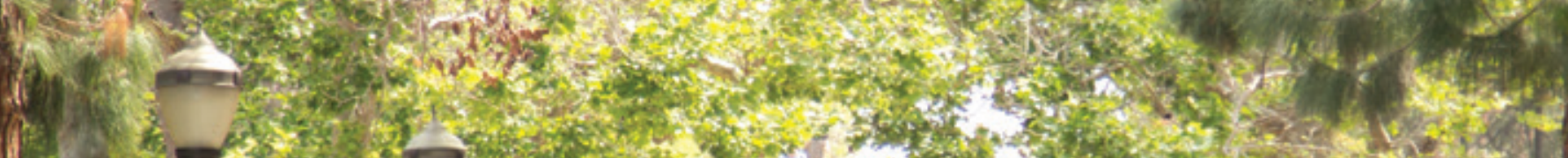

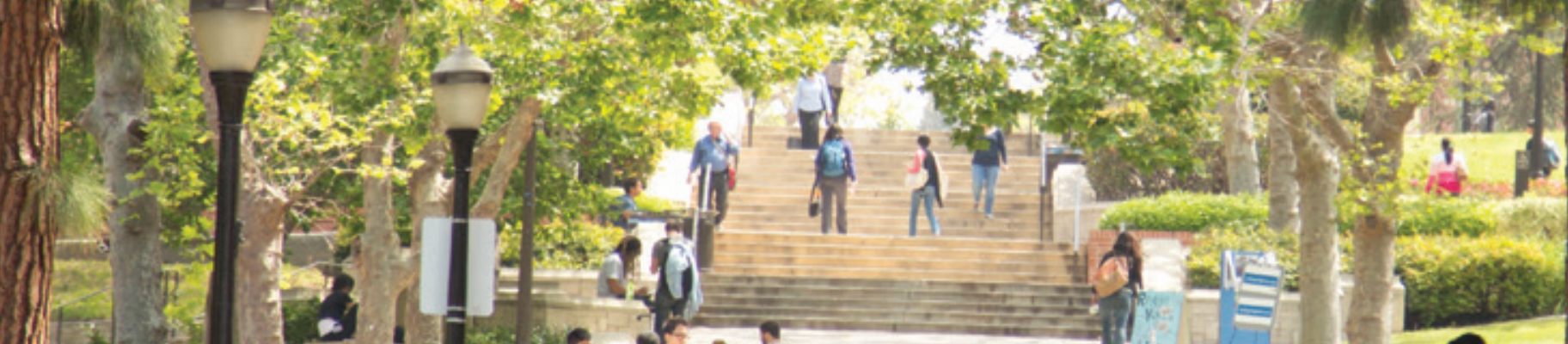

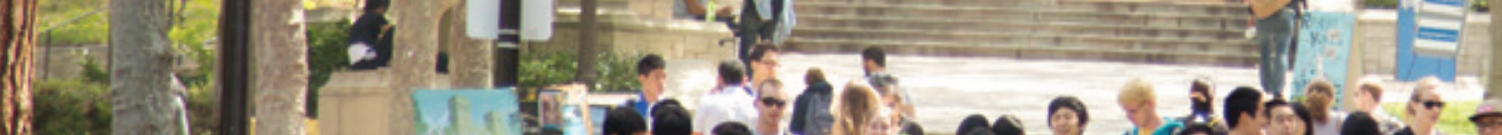

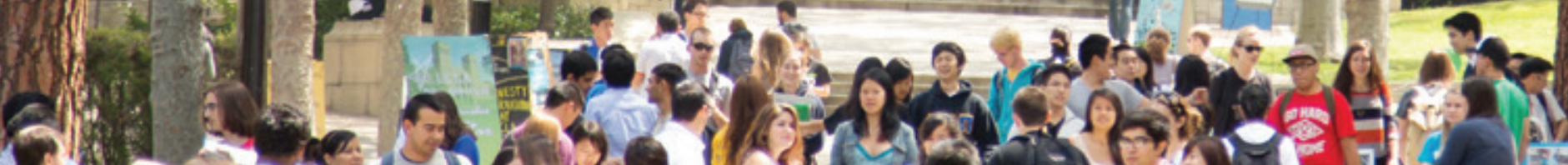

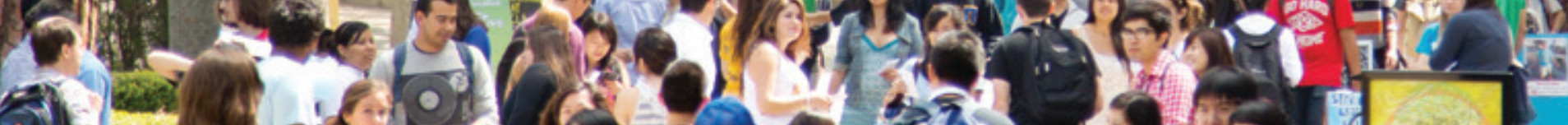
A) 1 it

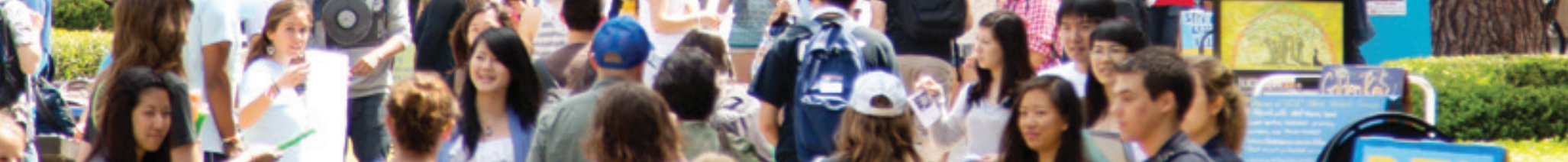

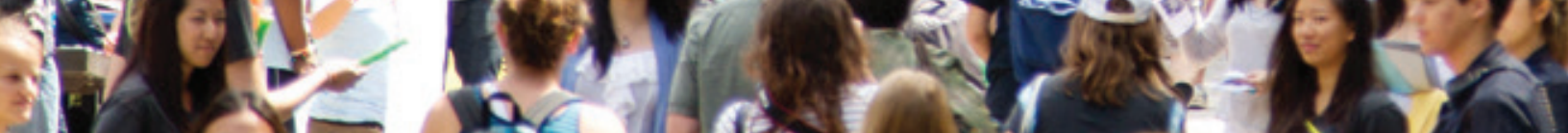

3 
EXECUTIVE SUMMARY: THE CASE

\section{FIVD RDASONS TO EXPAND COMMUNITY COLLEGE TRANSFER AT ATI INSTITUTIONS}



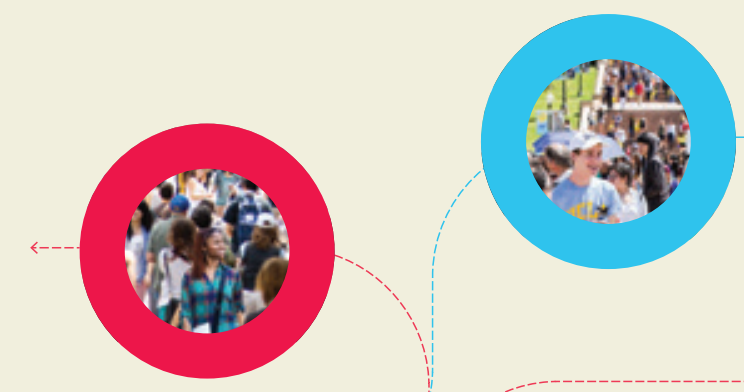

\section{EVEN THE HIGHEST}

\section{ACHIEVERS IN COMMUNITY} COLLEGE ARE OVERLOOKED.

Each year, 50,000 high-achieving low- and moderate-income community college students do not transfer to a four-year institution. Approximately 15,000 of these students have achieved a GPA of 3.7 or above, which would make them competitive at the nation's most selective schools. 
NEW STUDENTS WHO ARE TRANSFERS

ATI INSTITUTIONS

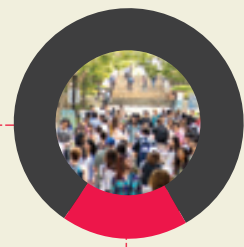

$18 \%$
ALL 4-YEAR INSTITUTIONS

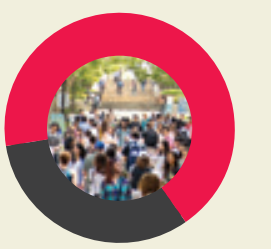

$32 \%$
THE ATI SECTOR CAN CREATE

SUBSTANTIALLY MORE OPPORTUNITY FOR COMMUNITY COLLEGE STUDENTS.

Across all ATI institutions, only 18 percent of new students are transfers, compared to 32 percent at all four-year institutions. Meanwhile, half of ATI institutions' transfer admissions webpages do not contain any references to transfer from community colleges.

MODEST CHANGE AT

INDIVIDUAL INSTITUTIONS CAN HAVE SUBSTANTIAL NATIONWIDE IMPACT.

If every ATI school enrolled an additional 20 lowand moderate-income community college transfer students as juniors each year, ATI would be a quarter of the way to reaching its 50,000 by-2025 goal-halfway if each enrolled an additional 40 transfer students.

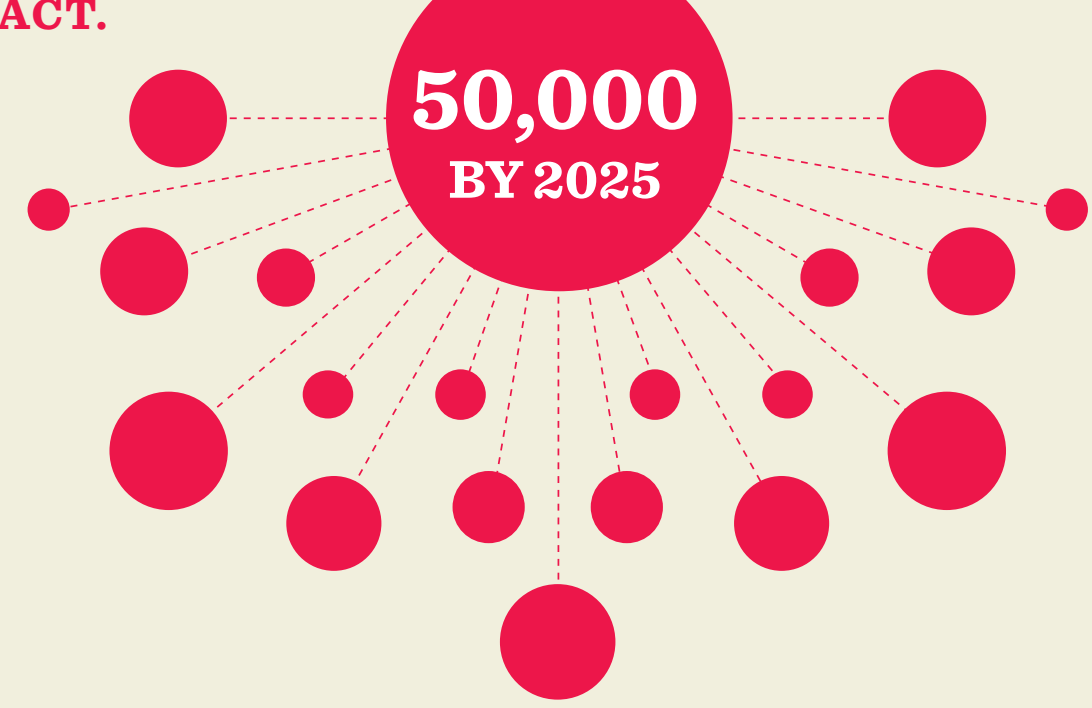

\section{What Can ATI Institutions Do to Be Part of the National Transfer Effort?}




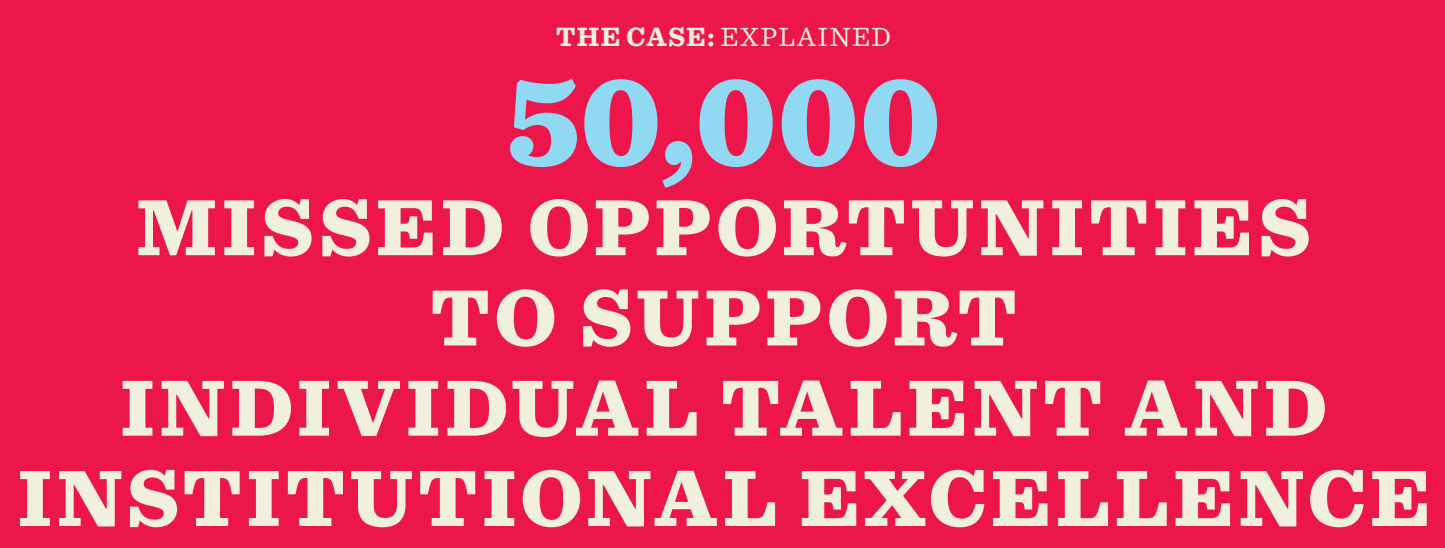




\section{Community Colleges-Serving Millions of the Nation's Most Underrepresented}

\author{
Today, community college students represent \\ approximately 3 ry percent of all entering first-time \\ degree-seeking undergraduates, with a total fall \\ enrollment of 6.4 million students each year. ${ }^{7,8}$ \\ Those enrollments are expected to reach 7.4 million \\ students by 2025. By comparison, the Western \\ Interstate Commission on Higher Education predicts \\ a steady average of about 3.44 million high school \\ graduates annually across the nation through $2023 .{ }^{9}$
}

Community colleges offer an affordable portal to higher education for some of the nation's most underserved groups. The average tuition and fees at two-year public colleges averages $\$ 2,978$ per year, less than a fifth the average cost at four-year institutions. ${ }^{10}$ Not surprisingly, then, college goers from high-poverty public high schools enroll in two-year colleges at about twice the rate of college goers from low-poverty schools. ${ }^{11}$ The result: A full two-thirds of community college students come from families with incomes in the bottom half of the income distribution. ${ }^{12}$ These enrollment trends are likely to persist, as lower-income students now make up the majority in public schools. Furthermore, data indicate a high degree of complexity in how socioeconomic disadvantage is experienced by community college students, with high representation of foster children, undocumented youth, and parenting students in the two-year population. For example, approximately a third of community college students report having a dependent in their care-more than double the incidence at four-year public and private institutions. ${ }^{13}$

Lower socioeconomic status also intersects with community college campus racial and ethnic diversity, especially for subpopulations of students that experience the highest degrees of childhood poverty. ${ }^{14}$ For instance, Black and Hispanic students are more likely to start in community colleges than their white peers. ${ }^{15}$ Additionally, while American Indians and Alaska Natives are underrepresented on four-year campuses, the enrollment of these groups in public two-year schools (about 1 percent of the student population) approximates the national distribution (about 1.3 percent of U.S. residents). ${ }^{16}$

Collectively, these data make clear that transfer pathways from community colleges present a significant opportunity for top colleges and universities to provide access to the students they have historically had the most difficulty reaching through traditional means.

\footnotetext{
7 U.S. Department of Education. National Digest of Education Statistics, Table 305.10. National Center for Education Statistics, 2016.

Note: These data points reflect a three-year average (2013-15).

${ }^{8}$ U.S. Department of Education. National Digest of Education Statistics, Table 303.30 National Center for Education Statistics, 2016.

Note: These data points reflect a three-year average (2013-15).

${ }^{9}$ Bransberger, Peace. (2017). Fewer Students, More Diversity: The Shifting Demographics of High School Graduates. Data Insights, July 2017.

${ }^{10}$ U.S. Department of Education. National Digest of Education Statistics, Table 330.10. National Center for Education Statistics, 2016.

Note: These data points reflect a three-year average (2013-15).

${ }^{11}$ National Student Clearinghouse Research Center. High School Benchmarks Report 2017: National College Progression Rates. NSC Research Center, October 2017.
} 


\section{An Abundance of Talented Community College Students Experience Abbreviated Opportunity}

In recent years, community colleges have come under scrutiny for low rates of degree attainment. While there is still much work left to be done to improve student success, there are numerous examples of excellence in community colleges. For instance, the Aspen Prize for Community College Excellence finalists have demonstrated strong outcomes in completion, labor market preparation, transfer, and equity. Moreover, Phi Theta Kappa's honor society, which inducts 134,000 new students each year, and the Jack Kent Cooke Foundation's Undergraduate Transfer Scholarship have long recognized community-college students with significant talent and achievement. One of the aims of this research was to estimate the number of lower-income community college students poised to excel at four-year institutions who are not being reached by these and other efforts.

Based on an analysis of national datasets, we found 41 percent of community college students, in their first year, obtain a first-year GPA between 3.0 and 4.0, and that 12 percent of new two-year students obtain at least a 3.7 GPA in their first year. ${ }^{17,18}$ Limiting the scope of the analysis to students who enroll in at least 24 credits in their first year, we found that 47 percent of these high-achieving, "transfer-ready" students do not transfer to any four-year institution within six years of entering higher education. Based on a threeyear average (2013-2015) of national fall enrollment trends of first-time students at two-year public institutions and estimates of students with belowmedian family incomes in 2011/12, we estimate that:

- More than 50,000 high-achieving lower-income community college students-those with at least a 3.0 GPA-do not end up transferring to a four-year institution within six years of beginning postsecondary education.

- Approximately 15,000 of these students would have GPAs in the 3.7-4.0 range, which is equivalent to the academic qualifications described in Hoxby and Avery, 2013. ${ }^{19}$

Because this analysis excludes community college students who began in the spring or summer terms, this figure almost certainly underestimates the number of high-achieving community college students that could excel after two-to-four-year transfer.
17 The primary data sources accessed for this analysis (see Appendix: "The Case" Study Design for more detail) were the National Center for Education Statistics' Digest of Education Statistics, Beginning Postsecondary Student Longitudinal Study 2004/09 (BPS 04/09), and National Postsecondary Student Aid Study 2011/12 (NPSAS 11/12).

Note: All estimates meet the NCES BPS reporting standard: Standard error represents less than 30 percent of the estimate.

\footnotetext{
${ }^{18}$ ATI Analysis: 2004/09 Beginning Postsecondary Students Longitudinal Study. National Center for Education Statistics.

19 Hoxby, Caroline, and Avery, Christopher. (2013). The Missing "One-Offs": The Hidden Supply of High-Achieving, Low-Income Students. Brookings Papers on Economic Activity, Spring 2013.
} 


\section{THE TALENT BLIND SPOT: \\ EACH COHORT, THOUSANDS OF HIGH-ACHIEVING PROSPECTIVE TRANSFER STUDENTS FAIL TO TRANSFER}

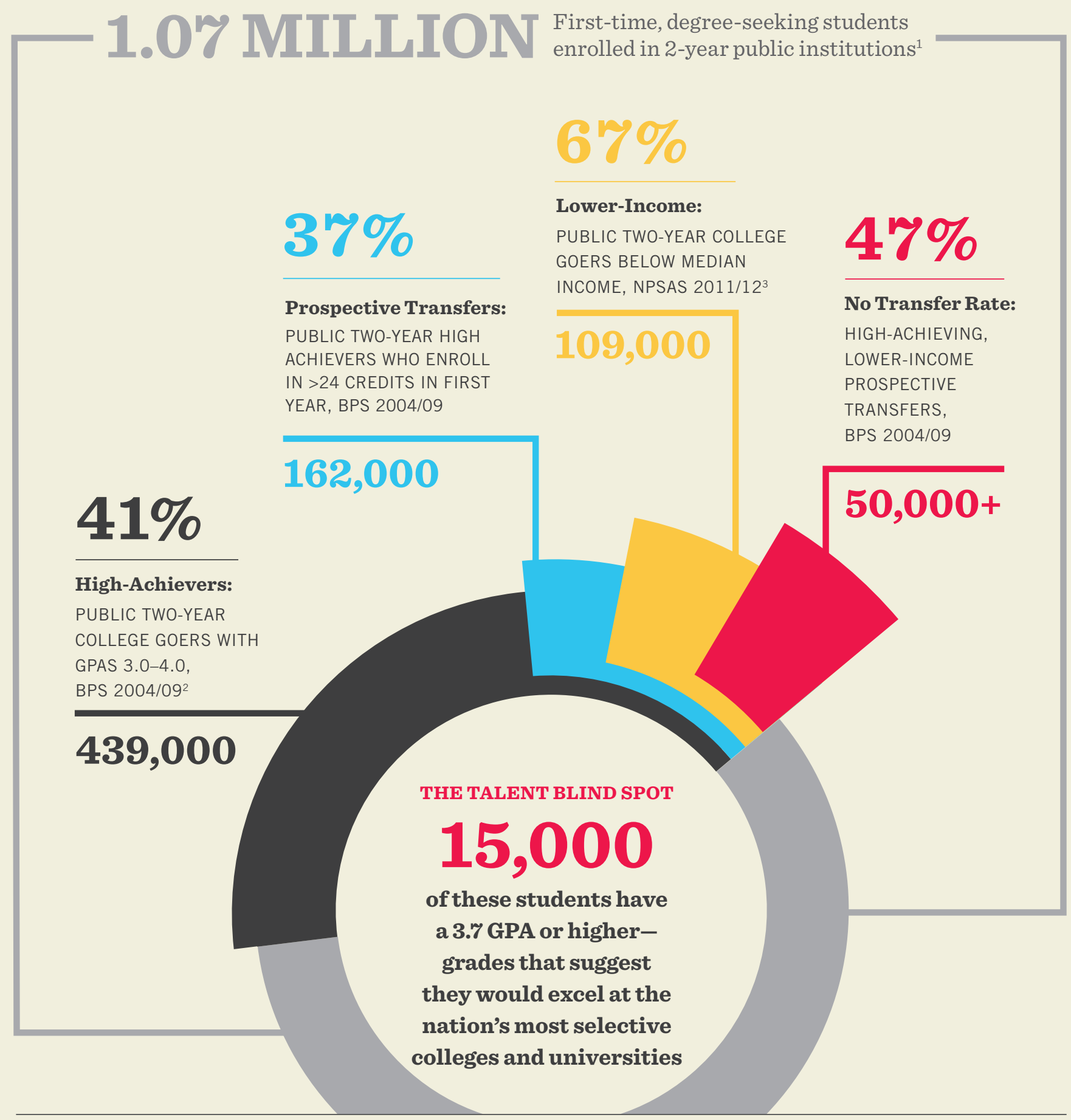

FIGURE REFERENCES

${ }^{1}$ U.S. Department of Education. National Digest of Education Statistics, Table 306.20. National Center for Education Statistics, 3-year average (2013-15).

${ }^{2}$ ATI Analysis: 2004/09 Beginning Postsecondary Students Longitudinal Study. National Center for Education Statistics.
${ }^{3}$ ATI Analysis of National Postsecondary Student Aid Study 2011-12 data.

* All estimates meet the NCES BPS reporting standard: Standard error represents less than 30 percent of the estimate. 


\section{Transfer Students Succeed When Supported}

\author{
The national data indicate that student success rates \\ are high when transfer from community college \\ to a four-year institution goes as intended-when \\ students transfer with an associate's degree. ${ }^{20}$ This \\ finding is consistent with prior studies, which demonstrate \\ that community college transfers to top colleges and \\ universities typically succeed at the same rates as students \\ who began at the same four-year institutions as first-year \\ students. ${ }^{21,22}$ Similarly, at the exemplar institutions we \\ consulted for "The Practical Guide," many indicated that \\ their community college transfer students graduate at \\ high rates comparable to those of the traditional student \\ body. These three schools illustrate the high level of college \\ readiness among community college students with GPAs in \\ the range identified in this study.
}

\begin{abstract}
Unfortunately, transfer rarely goes as intended-especially for lower-income students. Few transfer students leave community college with an award and only $36 \%$ of lowerincome transfer students attain a bachelor's within six years of beginning postsecondary education. ${ }^{23}$ To fully support transfer students, ATI institutions should partner with community colleges to address attrition risks and progression delays that exist before, during, and after transfer. The companion practice report provides specific guidance in this regard (see The Practical Guide).
\end{abstract}

\section{TRANSFER PATHWAYS ARE EFFICIENT, BUT LESS SO FOR LOWER-INCOME STUDENTS}

\section{TRANSFER, WHEN DONE RIGHT, OFFERS AN EFFICIENT PATH TO GRADUATION...}

\section{BUT TRANSFER RARELY GOES AS INTENDED, ESPECIALLY} FOR LOWER-INCOME STUDENTS ${ }^{3}$
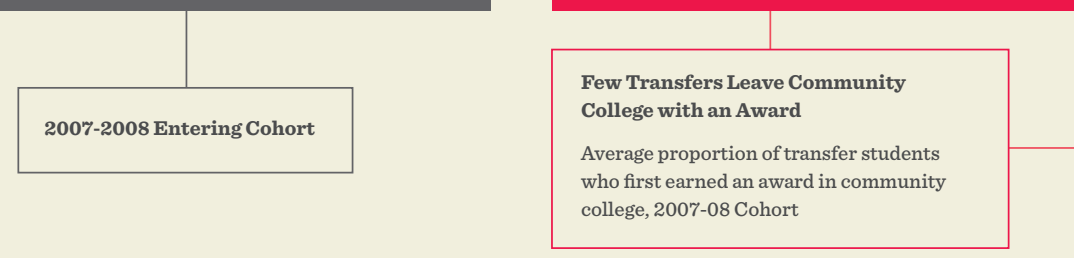

Lower-Income Transfer Students Complete Bachelor's at Lower Rates

Average proportion of transfer students who earned a Bachelor's degree six years after community college entry, 2007-08 Cohort

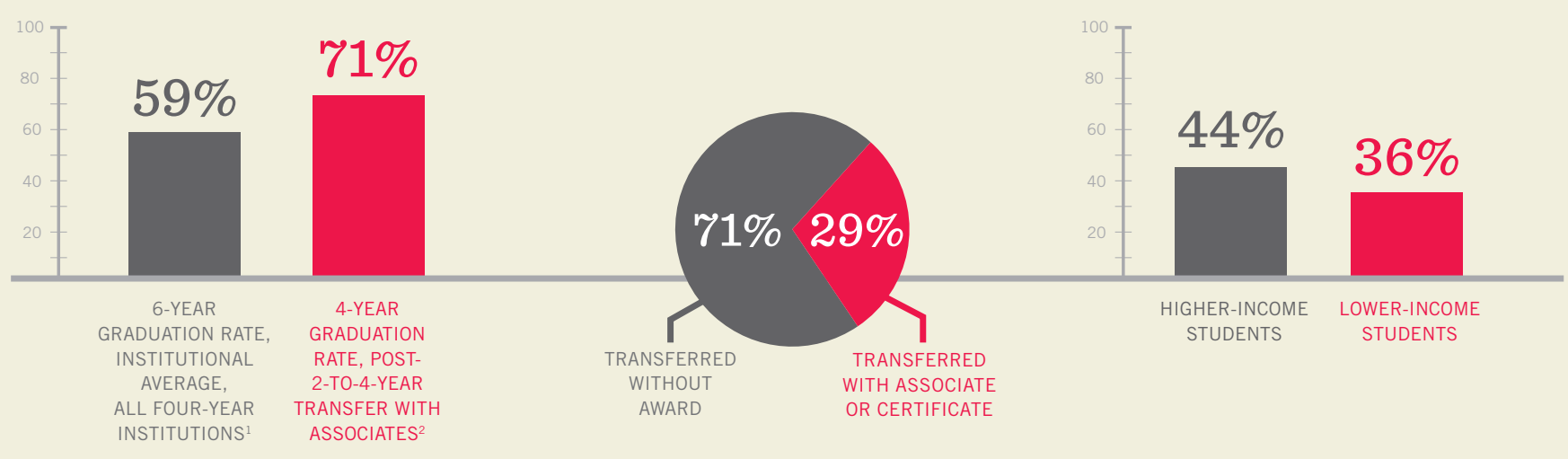




\section{Untapped Educational Excellence at Top Colleges}

\author{
While these observations are impossible to \\ capture through a national data review, qualitative \\ analysis conducted for this report-including \\ conversations with faculty and staff at several \\ institutions-and a literature review suggest that \\ community college transfer initiatives positively \\ impacted the broader academic and social \\ experience on their campuses in several ways.
}

\section{Classroom Enrichment}

Faculty from different disciplines described the transfer population as generally coming in with exceptional work ethic and focus, varied professional and life experiences, and diverse racial/ethnic and socioeconomic backgrounds. By expanding access to this population, transfer initiatives enriched classrooms, adding unique dimensions to discussions and group work.

"In many cases, transfer students from community colleges bring valuable work and life experience. For example, transfer students may come from careers in the military, manufacturing, or health care fields. From what I've seen, these skills translate well into an aptitude for hands-on, laboratory-based coursework and an applied lens to classroom concepts. These are exceptional skills and perspectives to include in our universities that enhance the learning experience for all involved."

- DR. BRIAN HOGAN, Teaching Associate Professor of Chemistry,

University of North Carolina at Chapel Hill
Faculty from different disciplines described the transfer population as generally coming in with exceptional work ethic and focus, varied professional and life experiences, and diverse racial/ethnic and socioeconomic backgrounds. By expanding access to this population, transfer initiatives enriched classrooms, adding unique dimensions to discussions and group work.

\section{Student Life}

Transfer initiatives often bring new dimensions to the broader four-year campus and local community. For instance, our contacts indicate that their community college transfer initiatives enrolled students who started new clubs (e.g., veteran and/or undocumented student affinity groups), volunteered in the local community organizations or hospitals, and spearheaded many of the support programs for transfer students-including peer mentoring, alumni outreach to community colleges, and transfer community-building events-that ultimately helped build bridges between the transfer and traditional student population. This corroborates findings from the 2014 Community College Transfer Initiative evaluation, which noted that their community college transfer students felt a strong desire to "give back."
"When initiatives are put in place to help
community college transfer students thrive
as individuals, it enables them give back
to the broader community. Our efforts to
support transfer students enable them to
engage in every corner of our campus-not
just the transfer community-and we're
a better university because of them."
- HEATHER ADAMS, Transfer Center, Program Director,
University of California, Los Angeles

${ }^{20}$ National Student Clearinghouse Research Center. (2012). Snapshot Report: Degree Attainment.

${ }^{21}$ Burack, Cathy; Lanspery, Susan; Shields, Thomas Piñeros; and Singleton, Sharon. (2014). Partnerships That Promote Success: Lessons and Findings from the Evaluation of the Jack Kent Cooke Foundation's Community College Transfer Initiative.

${ }^{22}$ Dowd, Alicia C.; Bensimon, Estela Mara; Gabbard, Glenn; Singleton, Sharon; Macias, Elsa; Dee, Jay R.; Melguizo, Tatiana; Cheslock, John; and Giles, Dwight. Transfer Access to Elite Colleges and Universities in the United States: Threading the Needle of the American

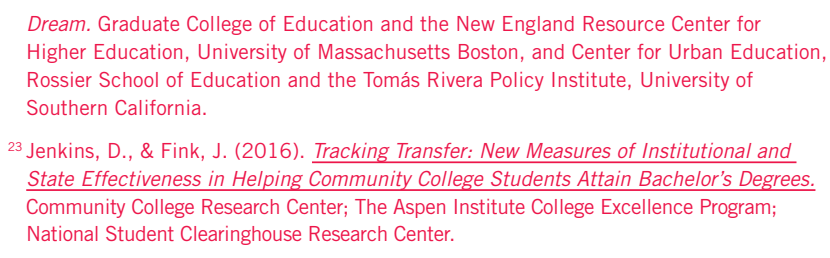




\section{The Economic Case for Transfer}

In addition to expanding access and enhancing educational quality, there is a compelling economic case to be made for increasing transfer students. Specifically, supporting community college transfer pathways may offer four-year colleges a financially sustainable strategy to provide an affordable education to substantially more low- and moderate-income students. To test this proposition, we sought to quantify the financial aid investment required to support community college transfer enrollment and bachelor's completion.

In comparison to data on traditional four-year students, data sources on financial aid for community college transfer students are sparse. Using data from a previous study by the Jack Kent Cooke Foundation (JKCF) to estimate financial aid investment, as well as national and proprietary data sets to approximate time-to-degree and lower-income transfer student enrollment by sector (see Appendix: "The Case" Study Design for more detail), we approximated the total savings in financial aid conferred by enrolling and graduating community college transfer students (Table 1). ${ }^{24,25,26}$
These analyses project that:

- In comparison to an equivalent cohort of traditional first-year students, the financial aid required to enroll and graduate an average cohort of community college transfer students is approximately $\$ 1.27$ million less at private and $\$ 3.58$ million less at public ATI institutions because of transfer students' shorter time-to-degree.

- At both public and private institutions, community college students can be enrolled for about three years before the cost in financial aid equals that of a traditional student.

To maintain affordability for both the student and the institution, both community colleges and fouryear institutions should provide robust guidance to students so that they can understand the costs associated with achieving their educational goals and the importance of doing so in a timely manner.

Estimating the Total Savings in Financial Aid Conferred by Enrolling and Graduating an Average Cohort of Lower-Income Community College Transfer Students at ATI Institutions

\begin{tabular}{|c|c|c|c|c|c|c|c|}
\hline SECTOR & STUDENT TYPE & $\begin{array}{c}\text { ESTIMATED } \\
\text { LOWER-INCOME } \\
\text { TRANSFER STUDENT } \\
\text { COHORT SIZE }\end{array}$ & $\begin{array}{c}\text { ANNUAL } \\
\text { FINANCIAL AID }\end{array}$ & $\begin{array}{l}\text { AVERAGE } \\
\text { TIME-TO-DEGREE } \\
\text { (YEARS) }\end{array}$ & $\begin{array}{c}\text { TOTAL } \\
\text { FINANCIAL AID } \\
\text { PER DEGREE }\end{array}$ & $\begin{array}{c}\text { TOTAL SAVINGS } \\
\text { PER TRANSFER } \\
\text { DEGREE }\end{array}$ & $\begin{array}{l}\text { TOTAL SAVINGS } \\
\text { ACROSS LOWER-INCOME } \\
\text { TRANSFER COHORT }\end{array}$ \\
\hline \multirow{2}{*}{ PRIVATE } & TRADITIONAL & \multirow{2}{*}{25} & $\$ 32,598$ & 4.03 & $\$ 131,370$ & \multirow{2}{*}{$\$ 50,781$} & \multirow{2}{*}{$\$ 1.27$ MILLION } \\
\hline & $\begin{array}{c}\text { COMMUNITY } \\
\text { COLLEGE TRANSFER }\end{array}$ & & $\$ 39,699$ & 2.03 & $\$ 80,589$ & & \\
\hline \multirow{2}{*}{ PUBLIC } & TRADITIONAL & \multirow{2}{*}{945} & $\$ 12,683$ & 4.29 & $\$ 54,410$ & \multirow{2}{*}{$\$ 3,785$} & \multirow{2}{*}{$\$ 3.58$ MILLION } \\
\hline & $\begin{array}{c}\text { COMMUNITY } \\
\text { COLLEGE TRANSFER }\end{array}$ & & $\$ 19,249$ & 2.63 & $\$ 50,625$ & & \\
\hline
\end{tabular}

${ }^{24}$ Burack, Cathy; Lanspery, Susan; Shields, Thomas Piñeros; and Singleton, Sharon. (2014). Partnerships that Promote Success: Lessons and Findings from the Evaluation of the Jack Kent Cooke Foundation's Community College Transfer Initiative.

Note: As part of their evaluation of the Jack Kent Cooke Foundation's (JKCF) Community College Transfer Initiative (CCTI) - an institutional grant program aimed at jumpstarting community college transfer opportunity at top colleges-Burack et al. collected data on average total annual financial aid awards to low-to-moderate-income two-year transfer students at five private and three public selective institutions-all of which are ATI-eligible.

${ }^{25}$ ATI Analysis: 2004/09 Beginning Postsecondary Students Longitudinal Study. National Center for Education Statistics.

${ }^{26}$ ATI Member Data and Analysis: (2013-15) 3-year Average Pell transfer student enrollment (Publics $945 n=15$, Privates $25 n=41$ ). 


\section{Assessing Limitations to Transfer Access Within the ATI Sector}

\section{To understand how transfer student enrollment across ATI institutions compared to national trends, we used publicly available data reported to the National Center for Education Statistics to measure the propor- tion of new fall enrollments (a combination of first-time or transfer-in) that entered as transfer students across two groups-the ATI sector and all Title IV-participating, degree-granting four-year public and private not-for-profit institutions. ${ }^{27}$ While 32 percent of all new fall enrollments were classified as transfer students across all four-year institutions, only 18 percent of new fall enrollments at ATI institutions were transfer students.}

Furthermore, this analysis likely overstates the proportion of new enrollments in the ATI sector as a result of community college transfer, as publicly reported data on transfer enrollment do not distinguish between transfer from two- and four-year institutions. To infer interest of the ATI sector in community college transfer, specifically, we conducted a text analysis of the transfer admissions webpages at all 290 ATI-eligible institutions. We searched for references to "community/two-year/technical colleges" or "associates" within three mouse clicks from the main transfer admissions webpage. For ATI-eligible institutions, references to community college transfer are present in about 50 percent of ATI-eligible institution transfer admission webpages. This is in comparison to 67 percent of a randomized sample of non-ATI schools.

These data are highly skewed by sector. For ATI-eligible privates, only 38 percent of websites contained references to community college transfer. Just 25 percent of ATI-eligible private institutions provide helpful information to community college students through their website-that is, information that extends beyond cursory references (i.e., no tailored information or specific partnership details are provided).

For ATI-eligible public institutions, 95 percent of websites contain references to community college transfer.

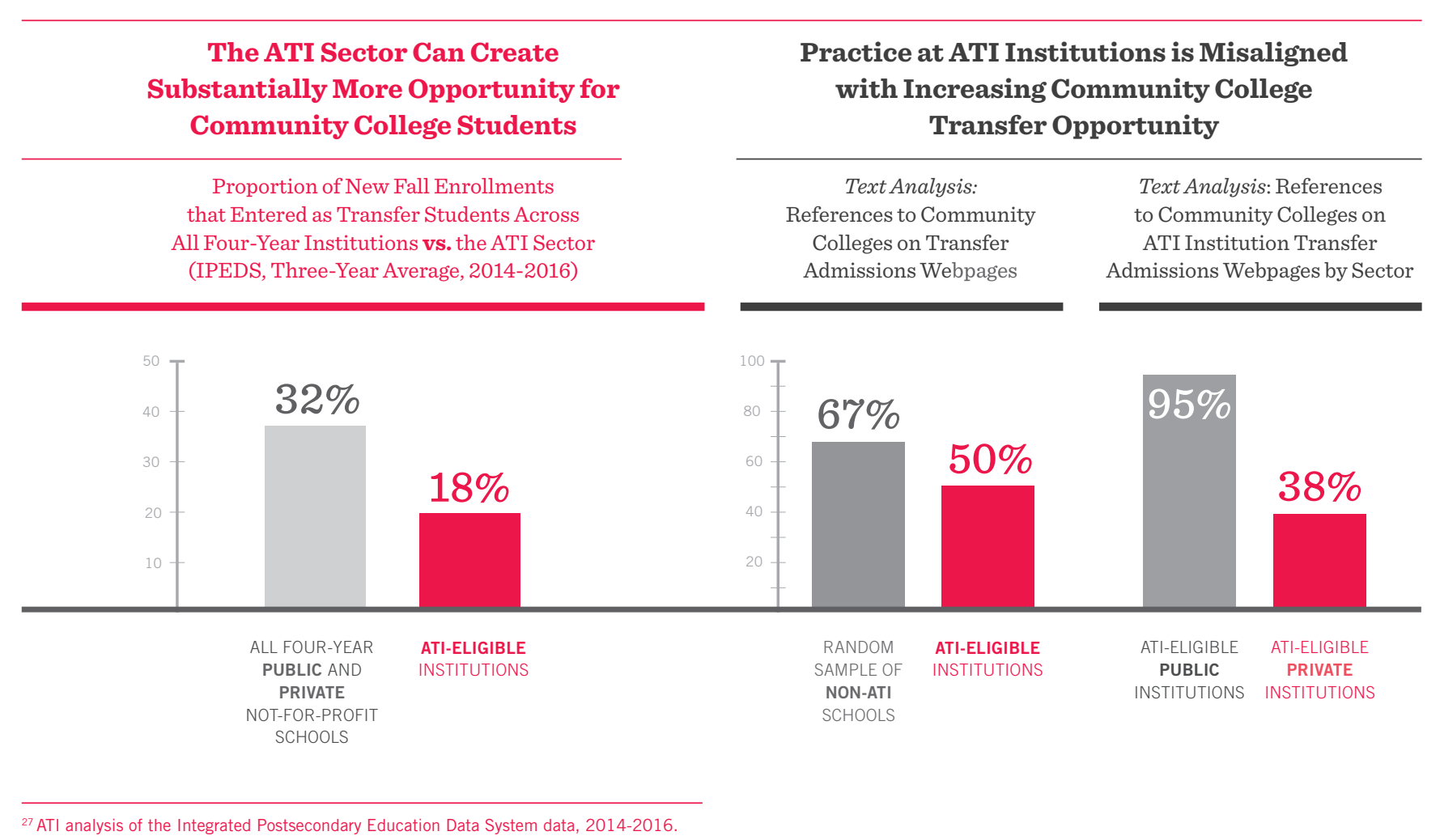


However, even among these institutions' websites, there is a great degree of variability in the accessibility of information. Public institution web content takes different forms:

- Full, high-visibility pages dedicated to prospective community college transfer pathways, and pre- and post-admission academic and social supports.

- Process-focused information with attention to admissions and transfer requirements for specific community colleges.

- No tailored information within three clicks of the main transfer admissions webpage.

While web content represents only one way in which fouryear institutions can engage with prospective transfer students, this analysis indicates the information, support, and opportunity gaps that community college students face in furthering their education, and points to an area where the ATI sector has substantial room for growth.

\section{Summary}

Despite their academic achievements, many talented community college students find their options to further their education limited. While ATI institutions might not have the capacity to serve all 50,000 community college students identified in this study, the sector still has the potential to achieve substantial change if more ATI institutions opened their doors to even a modest number of community college transfer students.

To illustrate, on average, if every ATI-eligible institution were to enroll an additional 20 community college students as juniors each year, ATI would be nearly a quarter of the way to reaching its 50,000-by-2025 goal-halfway there if each enrolled 40 more transfer students.
A PATH

FORWARD

A companion to this

report aims to support

ATI institutions in their

efforts to substantially

expand community

college transfer

opportunity across the

sector. "The Practical

Guide" highlights

stories from individual

ATI institutions-both

longstanding transfer

destinations and

relatively new adopters-

and builds on the

recommendations from

the Aspen Institute and

the Community College

Research Center's

Transfer Playbook. ${ }^{28}$

${ }^{28}$ Dean, KC; Fink, John; Jenkins, Davis; and Wyner, Joshua. (2016). The Transfer Playbook: Essential Practices for Two- and Four-Year Colleges. 


\section{A Road Map to Advancing Community College Transfer at ATI Institutions}

\section{THE INSTITUTIONAL CHALLENGE}

While many ATI institutions admit some community college transfer students, most struggle to align policies and practices within their institutions-as well as with their community college partners-with what is needed to achieve higher levels of transfer student access and success.

\section{A WAY FORWARD: THREE FUNDAMENTAL PRINCIPLES}

\section{Advancing Opportunity Through Strong, Leadership-Driven Partnerships}

Instead of viewing transfer purely as an enrollment strategy, ATI institutions must prioritize transfer throughout the organizationincluding at the highest levels-and organize internally to meet the unique needs of transfer students, develop mutually beneficial relationships with community colleges and their leaders, and cultivate two- and four-year faculty champions-key players in partnership development and the success of transfer students.
As a result of the historical lack of transfer opportunity across the ATI sector, community college students and their mentors tend to overlook ATI institutions when weighing transfer options. Even when ATI institutions are considered, the dearth of information and transparency on credit transfer, financial aid, and support systems can discourage students from applying or result in costly additional time-to-degree.

\section{Engaging and Advising Community College Students Early}

Rather than traditional recruiting tactics, ATI institutions should lean on established community college partnerships to build strong relationships with community college faculty and advisors-the main influencers of prospective students. Students' trusted mentors should be empowered to give comprehensive guidance early in the process, and four-year advisors should be readily available to answer specific transfer questions.
A compressed timeframe at their bachelor's institution leaves transfer students relatively little time to establish a sense of inclusion and engagement, adapt to new academic expectations, and pace toward on-time graduation, let alone participate in the highimpact experiences typically associated with the ATI sector. Despite these challenges-and their potentially costly consequencestoo few ATI institutions provide the tailored support needed to ensure that community college transfer students access the full range of experiences available.

\section{Fostering Holistic Transfer Student Success with Dedicated Supports}

While community college transfer students are likely to graduate, more needs to be done to support equitable and holistic success.

Specifically, ATI institutions should consider pre-transfer programming in partnership with community colleges to set students up for success as early as possible, robust orientation programming after admission, and continuous post-transition support to reinforce key messages when students need them most. ATI institutions should also consider that transfer students are likely to hail from communities historically underserved by higher educationincluding students with low-income backgrounds, students of color, parenting students, veterans, etc.-and connect students to tailored programming and resources as needed. 


\section{Appendix: "The Case" Study Design}

To understand the community college landscape and transfer student demographics and outcomes, we conducted a thorough review and analyses of nationally representative datasets, including from the U.S. Department of Education National Digest of Education Statistics, Integrated Postsecondary Education Data System, Beginning Postsecondary Student Longitudinal Study 2004/09 (BPS 04/09), National Postsecondary Student Aid Study 2011/12 (NPSAS 11/12), and National Student Clearinghouse Research Center.

\section{Expanded Methodology: Estimating the Number} of High-Achieving Low-and Moderate-Income Community College Students Who Do Not Transfer to a Four-Year Institution

The Beginning Postsecondary Student Longitudinal Study 2004/09 (BPS 04/09) tracked a cohort of entering students at three stages: the end of their first, third, and sixth year after first beginning their postsecondary studies. The data collected in the study included student demographics, persistence, academic performance, transfer, degree attainment, and time-to-degree. The BPS 04/09 dataset contains information on nearly 16,700 students. Similarly, the National Postsecondary Student Aid Study 2011/12 (NPSAS 11/12) is a comprehensive dataset on student financial aid based on a sample of approximately 95,000 undergraduate students. We interrogated these two datasets to ascertain the proportion of students who first started postsecondary education at public two-year institutions who were:

- High achieving, defined as those who attained between a 3.0 and a 4.0 GPA in their first year. (We also investigated the proportion of starting two-year students whose academic performance matched "high achievement" as defined by previous studies, specifically the 3.7 GPA benchmark used by Hoxby and Avery, 2013). ${ }^{29}$
- High achieving as defined above, and transfer-ready, defined as those who enrolled in at least 24 credits in their first year, such that they would be projected to complete an associate's degree in two or three years.

- Low- to moderate-income (lower-income), defined as those who came from families with below-median incomes in $2011(\$ 50,054$, according to the U.S. Census Bureau).

- High-achieving, transfer-ready as defined above and who did not transfer to a four-year public or private not-for-profit institution within six years of entering higher education.

To estimate the annual number of lower-income, high-achieving, transfer-ready students who do not transfer, we applied the rates calculated above to the three-year average of total national fall enrollment of entering students at two-year public institutions (2013-2015). Our estimate assumes that high academic achievement is equally distributed across income levels.

Expanded Methodology: Approximating the Total Savings in Financial Aid Conferred by Enrolling and Graduating Community College Transfer Students at ATI Institutions

We assumed the investment in financial aid that an ATI institution would make to fully support a lower-income community college transfer student through bachelor's completion would be a function of two variables:

- Average financial aid award amount per lower-income transfer student

- Average transfer student time-to-degree

\footnotetext{
${ }^{29}$ Hoxby, Caroline, and Avery, Christopher. (2013). The Missing "One-Offs": The Hidden Supply of High-Achieving, Low-Income Students. Brookings Papers on Economic Activity, Spring 2013.
} 
We used the Jack Kent Cooke Foundation's (JKCF) Community College Transfer Initiative (CCTI) evaluation's financial aid data from eight ATI-eligible institutions included in that study to estimate annual financial aid investment in lower-income community college transfer students. These figures were not inflation-adjusted for our calculations. Through the National Center for Education Statistics (NCES) BPS 2004/09 we were able to obtain the average time to bachelor's attainment (in years) of transfer students after completing an associate's degree. These two datasets also provided the equivalent data points for traditional students. The difference between the financial aid awarded per transfer student degree and traditional student degree constituted the institutional savings in financial aid investment per degree conferred by transfer enrollment.
To calculate the savings conferred across a cohort of lower-income transfer students, we estimated the average lower-income transfer student cohort size (broken out by sector) by taking a three-year average (2013-15) of the number of entering transfer students who were eligible for Pell grants, based on data submitted by a subset of ATI member institutions (public members $n=15$, private members $n=41$ ). Total savings in financial aid was a function of the savings per degree as calculated above and the estimated cohort size.

The amount of time that a community college transfer student could take to complete a bachelor's degree before the cost in financial aid invested exceeded that of a student admitted as a first-year was also calculated by taking the total cost in financial aid for a traditional student degree and dividing it by the annual financial aid investment to support a lowerincome community college transfer student. 
(3)

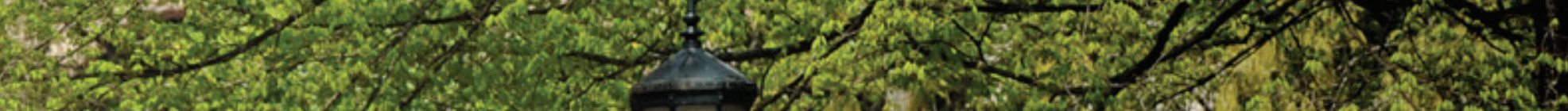

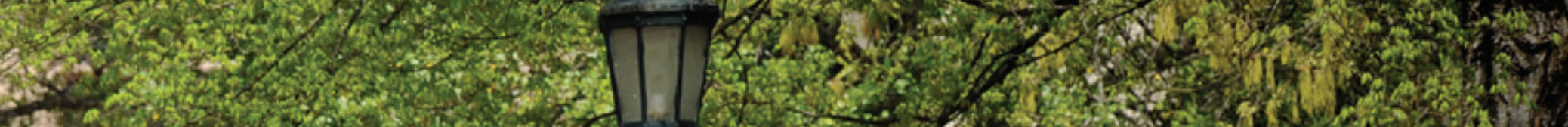
on: a

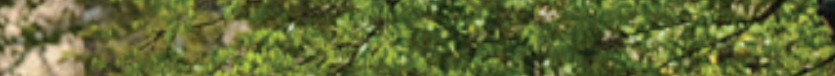

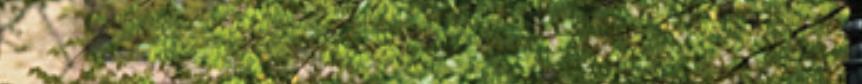

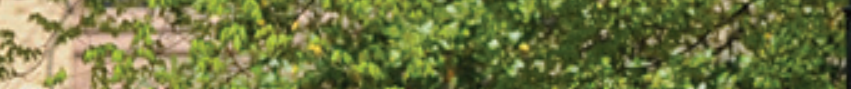

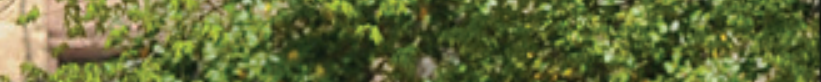

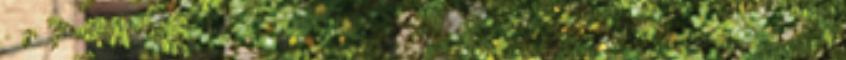
t. F

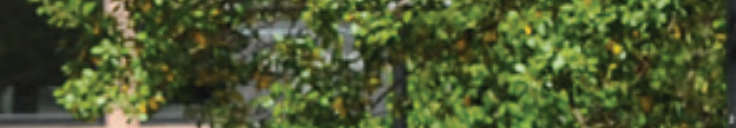
1 .

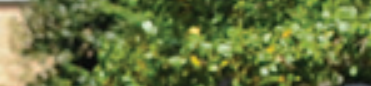

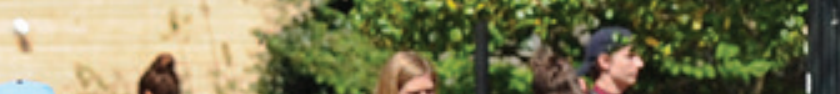

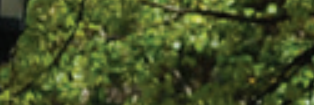
60.

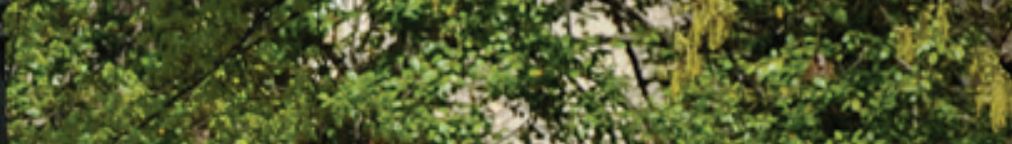

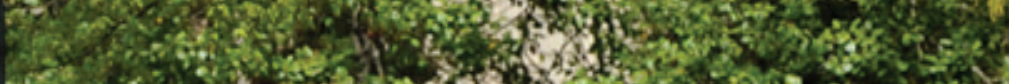

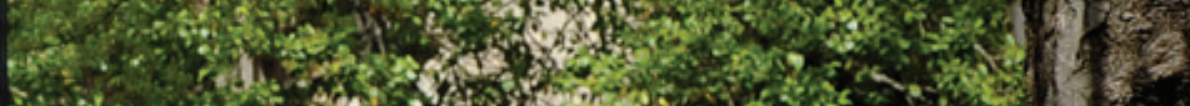

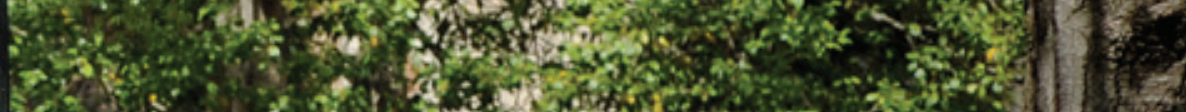

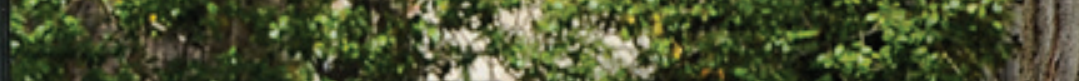

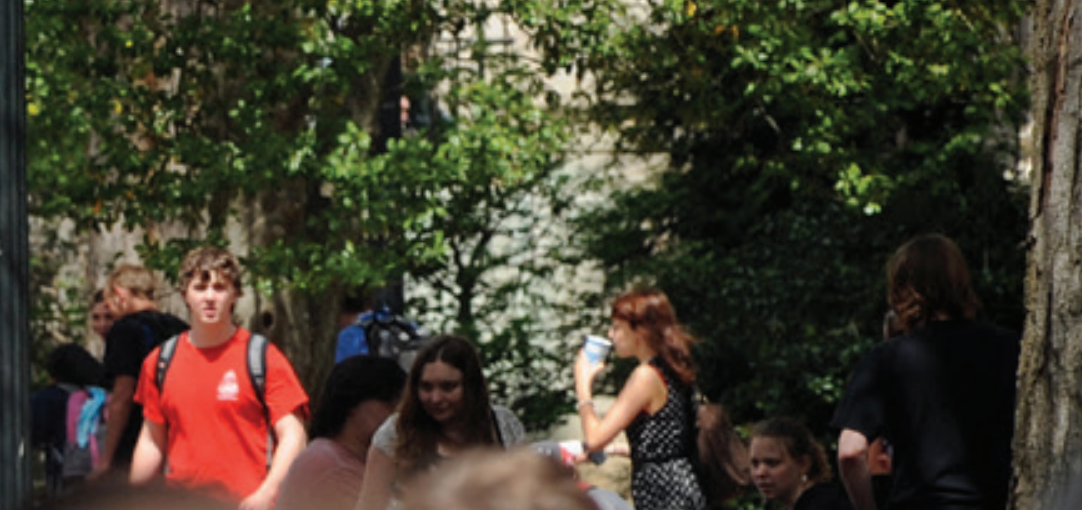
(2)

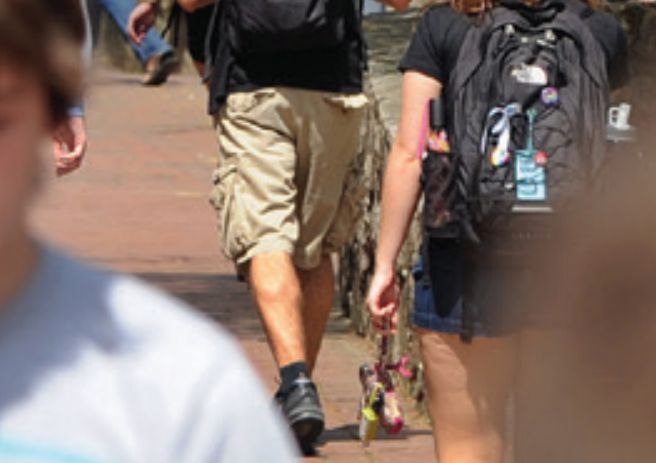

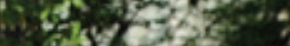

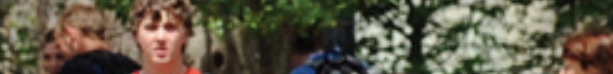
6

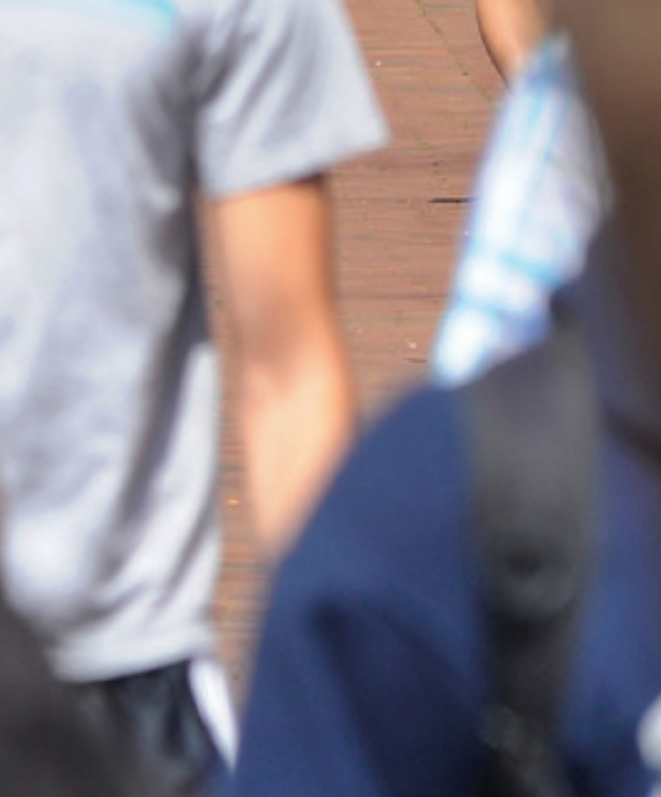


If every ATI school enrolled an additional 20 low- and moderate-income community college transfer students as juniors each year, ATI would be a quarter of the way to reaching its 50,000-by-2025 goal-halfway if each enrolled an additional 40 transfer students.
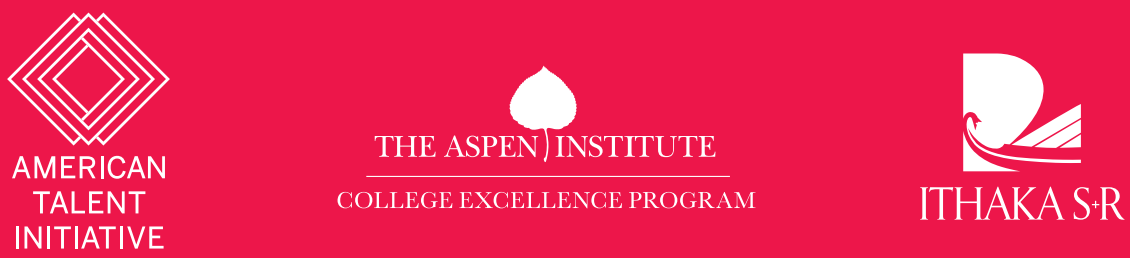